UDC 349.6.001

DOI https://doi.org/10.37687/2413-7189.2020.3.11

Sukhodolska A.A.,

Ph.D., Researcher

Educational and Research Center of Medical Law

of Taras Shevchenko National University of Kyiv

ORCID: 0000-0002-5794-9167

\author{
Tymoshenko M.O., \\ Ph.D., Associate Professor, \\ Vice-Rector \\ Private Higher Education Establishment "European University" \\ ORCID: 0000-0003-2584-5731
}

\title{
THE ENVIRONMENTAL PROBLEMS OF THE HIGHER EDUCATION
}

\section{ЕКОЛОГІЧНІ ПРОБЛЕМИ ВИЩОЇ ОСВІТИ}

The article is devoted to the right to education is under the obligation of the state to provide at least a minimum guarantee to ensure both the accessibility of educational services within the functioning of the relevant network of educational institutions and the provision of systematic professional knowledge that would take into account the environmental component.

It is established that the concept of freedom in law includes the freedom to choose any activity not prohibited by law, including the right to education as a condition of future employment. This concept is inextricably linked to the rights and responsibilities of man and citizen and is guaranteed by international law and the constitutions and laws of individual countries. Constitutional regulation of higher education and its environmental and ecological and legal components, appropriate programming of the legal consolidation of this brunch of social relations is an objective reflection of the general public significance and functional properties of the phenomenon of higher education for the personality development, society and state development, the embodiment of social value conditions of the globalized civilization development, accompanied by an increase in environmental challenges and threats.

The right to higher education should be understood as a Government-guaranteed opportunity for a person who already has the necessary level of basic education to obtain professional knowledge, skills, competences and their official recognition in order to meet the needs of society at a higher educational institution or scientific organization in accordance with established educational programs and standards and the state in training highly qualified specialists, as well as individuals in the intellectual, cultural and moral development with the bank of ecological knowledge of the acquired skills and knowledge implementation.

Key words: human rights and freedoms, freedom and choice, right to education, constitutional guarantees of the right to education.

Стаття присвячена проблемам реалізації права на освіту, обов'язку держави надати принаймні мінімальну гарантію забезпечення як доступності освітніх послуг у межах функціонування відповідної мережі навчальних закладів, так і надання систематичних професійних знань, які б враховували екологічний складник.

Встановлено, щзо поняття свободи у праві включає свободу вибору будь-якої діяльності, не забороненої законом, зокрема й право на освіту як умову майбутньої роботи. З'ясовано, щзо поняття свободи у праві включає свободу вибору будь-якої діяльності, не забороненої законом. Це стосується, зокрема, і права на освіту як умови майбутньої трудової діяльності. Це поняття нерозривно пов'язане з правами й обов 'язками людини і громадянина та гарантується як міжнародно-правовими актами, так і конституціями та законодавством окремих країн. Цей вид соціальних відносин є об'єктивним відображенням загальносуспільної значущості та функиіональних властивостей явища вищзӧ освіти для розвитку особистості, розвитку суспільства й держави, утілення соціально-ціннісних умов розвитку глобалізованої циивілізащії, щчо супроводжується збільшенням екологічних викликів і загроз.

Право на вищу освіту варто розуміти як гарантовану урядом можливість людині, яка вже має необхідний рівень базової освіти, здобути професійні знання, навички, компетенцію та їх офіиійне визнання з метою задоволення потреб суспільства у вищих навчальних закладах. Установа чи наукова організачія відповідно до встановлених освітніх програм і стандартів та держава беруть участь у підготовиі висококваліфікованих спеціалістів, а також осіб, які займаються інтелектуальним, культурним і моральним розвитком, з набором екологічних знань, набутих навичок та впровадженням знань.

Ключові слова: права і свободи людини, свобода та вибір, право на освіту, конституційні гарантії права на освіту. 
In the modern globalized world the higher education acts as a social agent, demonstrating the close interconnection of the personal and social components of the human civilization development. The concept of freedom is inextricably linked with human existence. At the same time, it is multidimensional, as evidenced by attempts to define and interpret it from ancient times to the present. Appropriate interpretations are primarily characteristic of philosophers, for whom the basic problem has always been to determine the relationship between human free will and its activities, regardless of external circumstances.

At the same time, freedom has always been seen not just as a person's choice, but as something higher, almost inaccessible. It is characteristic that such ideas were expressed not only by scientists of Antiquity or the Middle Ages, but also by contemporaries. Thus, S. Alekseev argues that "freedom is not the result of intellectual creation. $<\ldots>$ It is really given to people by nature itself, it is - "God's gift", one of the highest manifestations of human nature, the essence of the unique that is inherent in man as a being intelligent - of higher consciousness. And in this regard, freedom is the embodiment of the meaning of human life $<\ldots$.. " [17].

The measure of human freedom has always been its comparison with dependence/independence from coercion. In particular, according to F.A. Hayek, "the state of freedom is a state of relations between people, when the coercion of some against others will be minimal" [18]. At the same time, J.P. Sartre emphasized that man, as a free being, is always directed to the future and is ready to resist anything that will stand in his way. At the same time, I. Kant substantiated the understanding that man is not just an intelligent being, but also a moral one, who is guided by his own considerations, independent of the outside world, while adhering to certain norms.

In this context, the interpretation of freedom by philosophers is similar to the interpretation that lawyers invest in the concept of freedom. Thus, according to O. Punda, "freedom is an opportunity for the subject to express his will on the basis of awareness of the laws of development of nature and society; freedom is a person's ability to act in accordance with their own goals and interests, based on the knowledge of objective necessity (reality)" [19].

Freedom of law is a system of opportunities established by society to carry out their own behavior in accordance with the degree of necessity and desire determined by law in a certain period of time provided by the state [21]. As N.I. Litvinenko rightly notes, "we can talk about civil liberties, political freedom, religion, individual freedom and others. However, the established definition of freedom as a general scientific category can not be found in any of the sciences that studies man and society. Such categorical uncertainty significantly complicates the analysis, as it allows to carry out research mainly through the forms of manifestation of the phenomenon, and not because of its essential features" [20].

Human freedom is the basic concept of the problem of human rights and citizenship. It is characterized by the following features:

- all people are born free and equal in their dignity and rights;

- a person has the right to do anything that is not expressly prohibited by applicable law;

- all people are equal in legal capacity, legal assistance and legal protection;

- human freedom is an objective reality, it goes beyond the limits regulated by law, as it is influenced by other social norms (morals, ethics, religious norms, etc.) [22].

After all, the modernization of social and state development at the present stage is inseparable from the provision of comprehensive development of personality, which, in turn, is impossible without obtaining by the person the educational level for functioning in modern society [1]. It is during the realization of this right a person joins the process of acquiring knowledge, skills, information, that is, providing access to the spiritual and cultural values of human civilization, forming a system of professional adaptation and knowledge for participation in the system of interaction "social production environment" on the basis of human values, one of the most important of which is the conservation of nature for present and future generations. Such access to values is the most important social need for each person [2], the satisfaction of which contributes to the creation of favorable ecological and decent economic and social conditions for human and citizen life in not only environmentally safe but also eco-friendly.

At the same time, the realization of such right implies the organization and operation of a network of educational institutions designed to provide educational services to a person at all levels and stages of education. In turn, the process of providing such services must be objective, deriving from science, systematic and further in nature, from lower (pre-school) to higher (higher education) level.

Therefore, the constitutional and legal consolidation of the right to education and forms of its implementation through the higher educational institution activity as an organizational unit activity aims to promote the realization of the human right to higher education as an element of the subjective is key to the constituting the initial principles of the legal regulation of the economic activity of higher educational institutions as well as the right to education in general and the right to obtain professional environmental knowledge necessary for the performance of professional responsibilities in particular.

The right to higher education should be understood as a Government-guaranteed opportunity for a person who already has the necessary level of basic education 
to obtain professional knowledge, skills, competences and their official recognition in order to meet the needs of society at a higher educational institution or scientific organization in accordance with established educational programs and standards and the state in training highly qualified specialists, as well as individuals in the intellectual, cultural and moral development with the bank of ecological knowledge of the acquired skills and knowledge implementation [3; 4; 9].

Hence, the noted constitutional right consists, in her opinion, of the following eligibilities: 1) the right to higher education funded by budgetary rather than own funds; 2) the right to receive scholarships and other forms of financial support; 3) the right to use libraries and information funds free of charge; 4) the right to use university's infrastructure free of charge; 5) the right to provide housing in a hostel free of charge or for a minimal fee $[5 ; 6$, p. 236].

If classical human rights, also known in the theory of law as first generation rights, were largely aimed at restricting the State power $[7 ; 2$, p. $7-8 ; 11]$, then the right to higher education, like other educational rights, belongs to the positive, legally binding state rights (the so-called second generation rights), because for its realization it objectively requires the whole complex of actions of the state in to the person of its competent authorities in order to ensure the quantify of this right.

This regulation is particularly relevant in the context of considering the environmental content of the right to higher education. We believe that in favor of adopting the statement about the mixed - naturally positive - nature of the right to higher education in modern conditions suggests the features of this right as the dependence of its realization on the state policy and socio and economic development of the country, its evolutionary character, as well as programmatically - the purpose of mutual responsibilities of the state and the individual in the higher education [1]. Finally, the "positivization" of the subjective right to higher education is facilitated by its contemporary interpretation as a public-private, not exclusively private law phenomenon, which must take into account the mechanism of its state support $[2 ; 12$, p. 16].
An extensive network of higher educational institutions, as well as other educational institutions, aims to promote the right of citizens of Ukraine to higher education (part one of Article 1 of the Law of Ukraine on Higher Education [14]) on the basis of accessibility for every citizen of all forms and types of educational services that provided by the State; equality of conditions of each person for full realization of his abilities, talent, comprehensive development; continuity and diversity of education; (Article 6 of the Law of Ukraine "On Education" [15]). It is clear that in view of such prolonged delay in the adoption of the Law of Ukraine "On environmental education" it is possible to include provisions on the ecological content of higher education and to take into account the environmental and environmental legal minimum level of the labor in the process of employment and change of position and profession.

According to this analysis, the subjective right of a person to higher education is an element of the broader content of the right to education, encompassing the elements of environmental and environmental legal education. Such law has a mixed (natural and positive) nature, combines private and public law components in its content, provides for a high level of public and state recognition, including legitimation at the level of positive legislation, and above all at the constitutional level, which makes it possible its enjoyment of other environmental, social, economic and cultural rights.

The article deals with the research of the main issues of the environmental component of the essence and contents of the right to higher education. Leading scientific and theoretical approaches to defining the right to higher education as a set of subjective legal capacity of a person are outlined. The place and role of the right to higher education in the system of subjective human and citizen rights are considered. The essence of the right to higher education clarifies by the determination of the mixed (public-private) nature of this right and its relationship with natural and positive human rights. The research focused on the fact that the enjoyment of other environmental, social, economic and cultural rights depends on the realization of a person's right to higher education.

\section{References:}

1. Белл Д. Грядущее постиндустриальное общество: опыт социального прогнозирования. Москва : Академия, 1999. $783 \mathrm{c}$.

2. Костенко О. Культура і право - протидія злу : монографія. Київ : Аттика, 2008. 352 с.

3. Тодика Ю. Конституційно-правовий статус особи та громадянина в Україні : монографія. Київ : Юре Хауз, 2004. $368 \mathrm{c}$.

4. Костицький В. Організація безперервної екологічної освіти. Географічні аспекти управління волинськими ресурсами : збірник матеріалів конференції, м. Луцьк, 14-16 лютого 1991 р. Луцьк, 1991. С. 5-6.

5. Русін М. Право на вищу освіту та ії конституційна підтримка. Порівняльно-аналітичне право. 2016. № 5. C. $234-237$.

6. Мельничук О. Конституційно-правове забезпечення права на освіту в Україні в контексті європейського досвіду : дис. ... докт. юрид. наук : 12.00.02 ; Інститут держави і права імені В.М. Корецького НАН України. Київ, 2015.459 с. C. 236.

7. Шаповал Р. Конституційне право людини та громадянина на освіту в Україні. Право і Безпека. 2011. № 1. С. $29-35$.

8. Боняк В. Конституційне право людини та громадянина на освіту та його підтримка в Україні : дис. ... канд. юрид. наук : 12.00.02. Київ, 2005. 205 с. С. 5-6. 
9. Шевчук С. Концепція державних позитивних обов’язків у практиці Європейського суду з прав людини. Право України. 2010. № 2. С. 54-55.

10. Тодика Ю. Конституційно-правовий статус особи та громадянина в Україні : монографія. Київ : Юре Хауз, 2004. 368 c. C. $7-8$.

11. Костицький В., Кобан О. Обмеження законодавчої та судової влади : монографія. Київ : АртЕк, 2017.228 с. C. 27-39.

12. Лібанова Є. Соціальна стратифікація українського суспільства: спроба статистичного визначення та вимірювання. Українське товариство. 2003. № 1(2). С. 146-164.

13. Про вищу освіту : Закон України від 1 липня 2014 р. № 1556-VII / Верховна Рада України. Відомості Верховної Ради України. 2014. № 37-38. Ст. 2004.

14. Про освіту : Закон України від 23 травня 1991 р. № 1060-ХІІ / Верховна Рада УРСР. Відомості Верховної Ради УРСР. 1991. № 34. Ст. 451.

15. Лисенко М. Інноваційна парадигма вищої освіти України в умовах переходу до інформаційного суспільства : автореф. дис. ... канд. філос. наук : 09.00.10 ; Національний технічний університет України «Київський політехнічний інститут». Київ, 2013. 19 с.

16. Алексеев С. Философия права. Москва : Норма, 1999, 336 с. С. 19.

17. Гаєк Ф. Конституція свободи / пер. з англ. М. Олійник та А. Королішина. Львів : Літопис, 2002. 556 с. С. $93-94$.

18. Пунда О. Право на свободу : монографія. Харків : Еврика, 2006. 284 с. С. 12-13.

19. Литвиненко Н. Економічна свобода та соціально-економічний розвиток. Економічний вісник. 2013. № 2. С. 15-21.

20. Ярмол Л., Вандьо С. Поняття, значення свободи та її взаємозв'язок із правом. URL: http://science.lpnu.ua/sites/ default/files/journal-paper/2017/jun/4910/yarmolvandyo.pdf.

21. Кунченко-Харченко В., Печерський В., Трубін Ю. Правознавство : підручник. Київ : Кондор, 2011.472 с. 